\begin{tabular}{ll}
\hline & $\begin{array}{l}\text { Kastamonu Eğitim Dergisi } \\
\text { Kastamonu Education Journal }\end{array}$ \\
$\begin{array}{l}\text { Ocak 2019 Cilt:27 Sayı:1 } \\
\text { kefdergi.kastamonu.edu.tr }\end{array}$ & Başuru Tarihi/Received: 30.09 .2017 \\
& Kabul Tarihi/Accepted: 02.02 .2018 \\
Dol: 10.24106/kefdergi.2296
\end{tabular}

\title{
Algılanan Örgütsel Destek ve İşe Adanmışlık Arasındaki Ílişkinin İncelenmesi ${ }^{1}$
}

\section{An Analysis of the Relationship Between Perceived Organizational Support and Work Engagement}

\section{Öz}

\author{
Erdal MERiç², Didem ÖZTÜRK ÇiFTCi ${ }^{3}$, Filiz YURTAL ${ }^{4}$
}

Bu araştırmanın amacı, Milli Eğitim Bakanlığı'na bağıı kamu okullarında görev yapan öğretmenlerin örgütsel destek algısı ve işe adanmışlık düzeyleri arasındaki ilişkiyi incelemektir. Araştırmanın hedef evreni, Ordu ilinin en büyük üç ilçesi olan Altınordu, Ünye ve Fatsa'daki kamuya bağlı ilkokul ve ortaokullardan oluşmaktadır. Araştırmanın örneklemi, küme örnekleme yöntemi ile belirlenen, $20 \mathrm{ilk/ortaokulda} \mathrm{görev} \mathrm{yapan} \mathrm{öğretmenlerden} \mathrm{oluşmaktadır.}$ İlişkisel tarama modelinin kullanıldığı araştırmada veriler, "Algılanan Örgütsel Destek Ölçeği" ve "işe Adanmışlık Ölçeği" kullanılarak elde edilmiştir. Araştırma sonucunda, algılanan örgütsel destek ile işe adanmışlık arasında pozitif yönlü anlamlı bir ilişki olduğu ve öğretmenlerin işe adanmışıklarının \%14,7 oranında algılanan örgütsel destek düzeylerine bağlı olduğu ortaya çıkmıştır.

Anahtar Kelimeler: Algılanan örgütsel destek, işe adanmışlık, öğretmen.

\section{Abstract}

The aim of this research is to investigate the relationship between the perception of organizational support and the levels of work engagement of teachers at public schools under the Ministry of National Education. The research population consists of public primary and middle schools in the three biggest counties in the province of Ordu- Altnordu, Ünye and Fatsa. The sample of the research consists of teachers working in 20 primary/middle schools that were determined through cluster sampling method. In the research, which employs relational screening model, the data were obtained using the "Perceived Organizational Support Scale" and "Work Engagement Scale". Research results revealed that perceived organizational support and work engagement had a positive meaningful relationship, and the work engagement of the teachers depended on the level of the perceived organizational support by $14,7 \%$.

Keywords: Perception of organizational support, work engagement, teacher. 


\section{Extended Abstract}

Purpose: This research was conducted with the aim of investigating the relationship between the perception of organizational support and the levels of work engagement of teachers in active duty at public schools under the Ministry of National Education. In the research the extent of the effect of perceived organizational support on achieving work engagement has also been questioned.

Method :This research was formed with the relational screening model. The universe of the research consists of public primary and middle schools in the three biggest counties in the province of Ordu- Altnordu, Ünye and Fatsa. The sample of the research comprises of the teachers working at the 10 primary and 10 middle schools in these counties. Cluster sampling method was preferred in determining the sample. 375 teachers working at the schools in the sample voluntarily participated in the research. 352 scale forms which were completely filled by the teachers were included in the analyses. The research data were collected with "Perceived Organizational Support Scale" and "Work Engagement Scale", whose reliability and validity had been tested with previous researches. The reliability of the research scales were reevaluated with Cronbach's Alpha coefficient. Cronbach's Alpha values were 0,929 for "Perceived Organizational Support Scale" and 0,915 for "Work Engagement Scale". These values indicate that the reliability of the scales are quite high. Research data were analyzed via SPSS statistical software. In this context, Independent Samples $\mathrm{t}$-Test, One-way Analysis of Variance (ANOVA), correlation and regression analyses were applied. The meaningfulness level for the statistical analyses in the research was taken as 0,05.

Findings : While the perceived organizational support levels of the participants did not have a meaningful difference in terms of marital status, branch and education background, the perceived organizational support levels of male teachers were observed to be higher in comparison with their female colleagues.

No statistically significant difference on the participants' work engagement levels in terms of their gender and marital status variables. However it was determined that work engagement levels differentiated in a meaningful fashion according to branch, and form teachers were observed to have higher work engagement level than branch teachers. Additionally, the levels of work engagement meaningfully differentiated according to the education backgrounds, and teachers with associate degrees had higher work engagement levels than those with bachelor degrees.

On the correlation analysis, which was conducted to test the relationship among the variables, it was determined that there was a positive $(0,384)$ and meaningful $(p<0,05)$ relationship between perceived organizational support and work engagement. The results of the regression analysis for the effects of perceived organizational support on the level of work engagement indicate that the work engagement of the employees depends on the levels of perceived organizational support by $\% 14,7(\mathrm{R} 2=0,147)$. Furthermore it was also determined that a one-unit increase in the teachers' perceived organizational support level generates a 0,29-unit increase in work engagement.

Discussion and Conclusion : In the research, where whether the teachers' perception of organizational support has an effect on how they dedicate themselves to their jobs, it was determined that the levels of perceived organizational support of the participants differed meaningfully according to their genders, and that male teachers' perceived organizational support levels were higher than female ones. Rhodes and Eisenberger (2002) reached results that could confirm this finding on their meta-analysis study. As for the work engagement levels of the participants, no statistically significant difference was found in accordance with their genders. This result, is in compliance with the study conducted on service industry employees by Nigah, Davis and Hurrel (2012: 898). Accordingly, work engagement level was found not to differ according to the genders of the employees in a study carried out on 439 sales assistance in Australia by Zhang et al. (2014: 11).

No statistically meaningful difference the perceived organizational support and work engagement levels of the participants was found in terms the marital status variable. This can be interpreted as whether the participants are married or single does not affect their perceived organization support and work engagement levels in a considerable way. In parallel to this result, the results of a study conducted on a sample of bankers by Kaur and Aneet (2017) indicate that the marital status of the employees does not create a meaningful difference in their perceived organizational support levels.

No statistically meaningful difference could be found in the participants' perceived organizational support levels in terms of branches. However it was determined that their level of engagement differed in a meaningful way in terms of their branches, and that the level of form teachers' work engagement was higher than branch teachers. This may stem from the fact that form teachers take care of the same students in all classes during the whole training day and that's why they feel responsible for various conditions of the students therefor becoming more attached to their work.

No meaningful difference in the participants' perceived organizational support levels according to the educational background variable, whereas the work engagement levels were revealed to differ in meaningful fashion, and assistant degree teachers have higher work engagement levels than those of bachelor degree ones.

As result of the research it was revealed that there is a positive relationship between perceived organizational support and work engagement, and analysis results indicate that the engagement of employees depend on their levels of perceived organizational support by $14,7 \%$. This confirms the existence of the relationship which is the main issue of research. Furthermore, it was also observed that a one-unit increase in the perceived organizational support level of teachers leads to a 0,29-unit increase in the engagement level. Similarly, there are other researches done in other industries that confirm the relationship between the perceived organizational support and work engagement. Dai and Qin (2016: 54) determined that perceived organizational support affected the work engagement to a large extent on their study conducted with 350 workers in China as well as Caesens and Stinglhamber (2014) who reached the conclusion that perceived organizational support affects work engagement in a positive manner on a study they conducted in two private-sector businesses with a total number of 265 employees and 112 administrators.

In conclusion, this research reached the result that when teachers feel the support of the administration by their side, they will commit to their jobs more and take further responsibilities to achieve educational goals. 


\section{Giriş}

Son yıllarda gerek hizmet gerekse üretim sektörlerinde artan rekabet düzeyi, işletmeleri sahip oldukları kaynakları en verimli şekilde kullanma yönünde ne yapabileceklerini sorgulama noktasına getirmiştir. İşletmelerin sahip oldukları kaynaklar içinde en değerli ve eşsiz olanının çalışanlar olduğu düşünüldüğünde, çalışan memnuniyetini arttırma ve örgütsel hedeflere ulaşmak amacıyla örgüt ile çalışan arasındaki ilişkiyi geliştirme konusundaki çabaların öneminin her geçen gün arttı̆ı̆ söylenebilir.

Çalışanların örgütten ve örgütlerin de çalışanlardan beklentilerinin artmasıyla birlikte araşttrmacılar ve yöneticiler çalışan performansını arttırmak amacıyla yapılması gerekenleri araştırmaya başlamışlardır. Bu araştırmaların birçoğunda, çalışanların kendilerini örgütlerinin bir parçası hissetmeleri sonucunda, işlerine ve örgütlerine sahip çıkmaları sağlanıldığı zaman verimliliğin yükseleceği sonucuna ulaşılmıştı. Çalışılan örgüt tarafindan değer verilme ve örgüt desteğini hissetme gibi çalışanların beklentilerinin karşılanması olarak değerlendirilen algılanan örgütsel destek, çalışanların örgütleriyle gönül bağı kurmaları hususunda etkili olmaktadır. Çalışanların örgütten almış oldukları destek karşılığında, kendilerini örgütün bir parçası hissederek, sosyal değişim teorisinde de ifade edildiği gibi daha çok ve özverili çalışmaları beklenmektedir (Turunç ve Çelik, 2010a).

Algılanan örgütsel destek; örgütün, çalışanın örgüte yapmış oldukları katkı ve katılımına değer verdiğine ve çalışan refahını önemsediğine ilişkin algılar ile çalışanlarla ilgili faaliyetlerin örgütleri tarafindan gönüllü olarak gerçekleştirildiğine yönelik duygu ve inançlar şeklinde tanımlanmaktadır (Eisenberger, Huntington, Hutchison ve Sowa, 1986; Güney, Akalın ve İlsev, 2007). Örgütsel destek algısı, çalışanların arkasında örgütün varlığını hissederek kendilerini güvende hissetmelerini sağlayacaktır. Örgütün desteğini hisseden çalışanlar, işlerine daha sıkı bağlanarak uzun süreler boyunca örgütlerinden ayrılmayı düşünmeyecektir (Özdevecioğlu, 2003). Dolayısıyla örgütsel destek algısı yüksek olan çalışanların örgüt yararına davranışlar gösterme eğilimi de yüksek olacaktır (Eisenberger ve diğerleri, 1986).

Amerikan Psikoloji Derneği (APA) başkanı Prof. Martin Seligman öncülüğünde ortaya çıkan pozitif psikoloji akımı, insanların eksik ya da negatif yönlerine değil olumlu yönlerine odaklanarak bu yönleri geliştirme temeline dayanmaktadır. 1990'lı yılların sonlarından itibaren söz konusu pozitif psikoloji yaklaşımının yönetim anlayışında da köklü değişimlere yol açttğı ve olumsuz duygu ve davranışların yerini olumlu yaklaşımlara bıraktığı söylenebilir. İşe adanmışık kavramı da, söz konusu pozitif etkinin örgütsel yansıması olan pozitif örgütsel davranış yaklaşımının, çalışma yaşamında ve yönetim alanındaki etkileri sonucu ortaya çıkmıştır. Kendisini, çalıştı̆ı işe yürekten adamış ve işiyle özdeşleşmiş çalışanların, diğerlerinden daha yüksek performans sergiledikleri, daha fazla sorumluluk alıp, aktif davranışlar sergilemeye daha istekli oldukları ve diğer çalışanlarla karşılaştrııdığında öğrenme motivasyonlarının çok daha yüksek olduğu görülmüştür (Bostancı ve Ekiyor, 2015).

Örgütsel bağlıık ile yakından ilişkili olmasına rağmen, işe adanmışlık farklı bir kavramdır. Çalışanın örgüte olan sadakatini anlatan örgütsel bağlılık örgüte odaklanırken işe adanmışlığın odak noktası işin kendisidir (Ardıç ve Polatcı, 2009). Chusmir (1982) işe adanmışığı, çalışanların kendilerini işleri ile bütünleştirmelerine yönelik tutumları olarak ifade etmektedir (Akt: İnce, 2016). İşe adanmışlık kavramı ilk kez Kahn tarafindan ortaya atılmıştır. Kahn (1990) işe adanmışlığı psikolojik bir durum şeklinde değerlendirerek "Çalışanların kendilerini fiziksel, duygusal ve bilişsel anlamda bütünüyle çalıştıkları işe odaklamaları" şeklinde ifade etmiştir. İşe adanmışlık kavramı, Schaufeli, Salanova, González-Romá ve Bakker (2001) tarafindan da kendini adama, yoğunlaşma ve dinçlik boyutları ile ilişkilendirilebilecek, çalışanın işi konusunda hissettiği pozitif zihinsel ve bilişsel durum şeklinde tanımlanmıştir.

Öğretmenlerin örgütsel adanmışlık düzeyleri, okuldaki öğretmenlerin birbirleriyle ve öğrencileriyle olan etkileşim ve iletişimine, yapılan işlerin niteliğine ve öğretmenlerin mesleklerini algılama düzeylerine bağlıdır. Öğretmenlerin örgütlerine ve işlerine karşı adanmışlıklarının düşük olması, iş başarılarını da düşürebilmekte ve okulda verimsizliğe neden olabilmektedir. Adanmışlık düzeyi düşük olan öğretmenlerin, çalışma ortamında sergileyebileceği engelleyici davranışlar, eğitim kurumlarının önceden belirlenen hedeflere ulaşmasında da sapmalara neden olabilmektedir (Celep, 1998). Dolayısıyla eğitimsel hedeflerin gerçekleştirilmesi noktasında öğretmenlerin işe adanmışlık düzeylerinin yüksek olması oldukça önem arz etmektedir.

Alan yazın incelendiğinde, algılanan örgütsel desteğin farklı kavramlarla ilişkisi konusunda çeşitli kurumlarda çalışanlar (Akkoç, Çalışkan ve Turunç, 2012; Alparslan, Can ve Oktar, 2014; Demircan Çakar ve Yıldız, 2009; Güney, Akalın ve İlsev, 2007; Kaplan ve Öğüt, 2012; Ötken, 2015; Özbek ve Kosa, 2009; Özdevecioğlu, 2003; Tokgöz, 2011; Turunç ve Çelik, 2010a; Turunç ve Çelik, 2010b; Uçar ve Ötken, 2010, Yılmaz ve Görmüş, 2012) ve eğitim kurumlarında çalışanlar (Eğriboyun, 2013; Eisenberger ve diğerleri, 1986; Kasalak ve Bilgin Aksu, 2014; Sökmen, Ekmekçioğlu ve Çelik, 2015) ile ilgili araştırmalar bulunmaktadır. İşe adanmışlık konusunda ise çeşitli kurumlarda çalışanlar (Bostancı ve Ekiyor, 2015; 
Çalışkan, 2014; Keleş, 2014; Maden Eyiusta, 2015; Nigah, Davis ve Hurrel 2012; Özyılmaz ve Süner, 2015; Zhang, Avery, Bergsteiner ve More, 2014) ve eğitim kurumlarında çalışanlar (Celep, 1998; Celep, Doyuran, Sarıdede ve Değirmenci, 2004) ile ilgili araştırmalar yapılmıştır. Çeşitli kurumlarda çalışanların, örgütsel destek algıları ile işe adanmışlık düzeylerini ele alan sınırlı sayıda (Caesens ve Stinglhamber, 2014; Dai ve Qin, 2016; İnce, 2016) çalışma bulunmasına rağmen öğretmenlerin örgütsel destek algıları ile işe adanmışıı düzeylerini birlikte irdeleyen herhangi bir araştırmaya rastlanılmamıştır. Buradan hareketle bu araştırmada öğretmenlerin örgütsel destek algıları ile kendilerini yaptıkları işe adamaları arasındaki ilişki araştırılmaya değer bulunmuştur. Bu araştırma, Milli Eğitim Bakanlığı bünyesindeki kamuya ait okullarda görev yapan öğretmenlerin, örgütsel destek algıları ile işe adanmışlık düzeyleri arasındaki ilişkiyi incelemek amacıyla gerçekleştirilmiştir. Bu amaçla öğretmenlerin örgütsel destek algısı ve işe adanmışlık düzeyleri cinsiyet, medeni durum, alan ve eğitim durumu değişkenlerine göre tespit edilmiş; algılanan örgütsel desteğin işe adanmışlık düzeyini ne derece yordadığı incelenmiştir.

\section{Yöntem}

\subsection{Araştırmanın Modeli}

iliş̧kisel tarama modeli ile yapılandırılan bu araştırmada, öğretmenlerin örgütsel destek algıları ile işe adanmışlık düzeyleri arasındaki olası ilişkiyi incelemek amaçlanmıştır. iliş̧isel tarama modeli, iki veya daha fazla değişken arasında birlikte değişim varlığını veya düzeyini belirlemek amacıyla tercih edilen bir yaklaşımdır (Karasar, 2014).

\subsection{Evren ve Örneklem}

Araştırmanın hedef evreni Ordu ilinin en büyük üç ilçesi olan Altınordu, Ünye ve Fatsa'daki kamuya bağlı ilkokul ve ortaokullardan oluşmaktadır. Araştırmanın örneklemi Merkez ilçe olan Altnnordu'dan 4 ilkokul ve 4 ortaokul, Ünye ve Fatsa ilçelerinin her birinden ise 3 ilkokul ve 3 ortaokul olmak üzere toplam 10 ilkokul ile 10 ortaokulda görev yapan öğretmenlerden oluşmaktadır. Örneklemin belirlenmesinde ise küme örnekleme yöntemi tercih edilmiştir. Bu amaçla, ilk olarak evrende yer alan tüm okullar, ilkokul ve ortaokul şeklinde küme olarak seçilmiş ve listelenmiştir. Daha sonra bu listelerde yer alan ve basit seçkisiz örnekleme yöntemi ile belirlenen okullar araştırmanın örneklemini oluşturmuştur.

Ölçeklerin uygulanabilmesi için Ordu Milli Eğitim Müdürlüğünden izin alınmasının ardından okullara gidilerek önce okul müdürü, sonra da öğretmenler ile görüşülüp araşttrma konusunda gerekli bilgilendirme yapılmış ve gönüllü 375 öğretmen araştırmaya dâhil edilmiştir. Ölçek formları öğretmenlere dağıtılıp, doldurulması için yeterli zaman tanınmış ve doldurulan ölçekler elden teslim alınmıştır. Eksiksiz doldurulan 352 ölçek analizlere dâhil edilmiştir.

Katılımcıların demografik özelliklerine ait bilgiler, anket formunun ilk bölümünde yer alan sorulara katlımcıların vermiş oldukları cevapların frekans ve yüzde dağılımları değerlendirilerek elde edilmiş ve Tablo 1'de gösterilmiştir.

\section{Tablo 1: Katilımcılara Ait Demografik Bilgiler}

\begin{tabular}{llcc}
\hline & Grup & Frekans (f) & Yüzde (\%) \\
\hline \multirow{3}{*}{ Cinsiyet } & Kadın & 139 & 39,5 \\
& Erkek & 213 & 60,5 \\
& Toplam & 352 & 100 \\
\hline \multirow{3}{*}{ Medeni Durum } & Evli & 325 & 92,3 \\
& Bekâr & 27 & 7,7 \\
& Toplam & 352 & 100 \\
\hline \multirow{3}{*}{ Alan } & Sını Öğretmeni & 149 & 42,3 \\
& Branş Öğretmeni & 203 & 57,7 \\
& Toplam & 352 & 100 \\
\hline \multirow{3}{*}{ Eğitim Durumu } & Ön Lisans & 54 & 15,3 \\
& Lisans & 285 & 81 \\
& Lisansüstü & 13 & 3,7 \\
& Toplam & 352 & 100 \\
\hline
\end{tabular}

Tablo 1 incelendiğinde, katlımcıların \%60,5'i erkek, \%39,5'i ise kadın öğretmenlerden oluşmakta ve \%92,3'ünün evli, \%7,7'sinin bekâr olduğu görülmektedir. Katılımcıların \%42,3'ü sınıf öğretmeni iken \%57,7'si ise branş öğretmenidir. Katılımcıların önemli bir kısmı (\%81) lisans mezunu iken ön lisans mezunu öğretmenler \%15,3 ve lisansüstü eğitim gören öğretmen sayısı ise sadece \%3,7'dir. Lisansüstü eğitim gören öğretmen sayısı oldukça düşüktür. 


\subsection{Veri Toplama Araçları}

Araştırma verileri, güvenirlik ve geçerlikleri daha önceden yapılmış olan araştırmalarla denenen "Algılanan Örgütsel Destek Ölçeği" ve "işe Adanmışık Ölçeği" ile toplanmıştır.

\subsubsection{Algılanan Örgütsel Destek Ölçeği}

Öğretmenlerin örgütsel destek algıları, Eisenberger ve diğerleri (1986) tarafindan geliştirilen ve Türkçeye uyarlaması Yılmaz (2014) tarafindan yapılan 8 maddeden oluşan "Algılanan Örgütsel Destek Ölçeği" (Survey of Perceived Organizational Support- SPOS) ile ölçülmüştür. 5’li Likert şeklinde olan ölçekte puanlar "Hiçbir zaman (1)" ile "Her zaman (5)" arasında değişmektedir. Ölçekten alınan yüksek puanlar, yüksek düzeyde örgütsel destek algısını göstermektedir. Yılmaz (2014) tarafindan yapılan güvenirlik analizinde ölçeğin Cronbach's Alpha değeri 0,84 olarak hesaplanmıştr.

Bu araştirmada ölçek için hesaplanan Cronbach's Alpha değeri 0,929 olarak bulunmuştur. Ortaya çıkan bu değer, ölçek güvenirliğinin oldukça yüksek düzeyde ve verilerin içsel tutarlıklarının çok iyi olduğunu göstermektedir.

\subsubsection{Işse Adanmışlık Ölçeği}

Öğretmenlerin işe adanmışlık düzeyleri, Schaufeli ve Bakker (2003) tarafindan geliştirilen ve Türkçeye uyarlaması Özkalp ve Meydan (2015) tarafindan yapılan 9 maddeden oluşan Utrecht "iş̧e Adanmışlık Ölçeği” (UWES-9) kullanılarak belirlenmiştir. 5'li Likert şeklinde olan ölçekte puanlar "Hiçbir zaman (1)" ile "Her zaman (5)" arasında değişmektedir. Ölçekten alınan puanların artması işe adanmışlı̆ın arttğını göstermektedir. Özkalp ve Meydan (2015) tarafindan yapılan güvenirlik analizinde ölçeğin Cronbach's Alpha değeri 0,83 olarak hesaplanmıştır.

Bu araştırmada işe adanmışlık ölçeğine ait Cronbach's Alpha değeri 0,915 olarak hesaplanmıştır. Bu değer, ölçek güvenirliğinin yüksek düzeyde olduğunu ifade etmektedir.

\subsection{Verilerin Analizi}

Araştırma verileri SPSS istatistik programı aracılı̆̆ıyla çözümlenmiştir. Veri girişleri tamamlandıktan sonra, veri setinin normal dağılımını test etmek amacıyla çarpıklık ve basıklık değerleri kontrol edilmiştir. Alan yazında çarpıklık ve basıklık değerleri ile ilgili Byrne (2010) basıklık değerinin 5'ten küçük olması durumunda veri setinin normal dağıldığını; Kline (2016) ise çarpıklık değerinin \pm 3 ; basıklık değerinin ise \pm 10 aralığında olmasının veri setinin normal dağılım gösterdiğinin belirtisi olarak kabul edilebileceğini ifade etmektedir. Algılanan örgütsel destek ölçeği için çarpıklık değeri $-0,605$, basıklık değeri 0,101; işe adanmışlık ölçeği için çarpıklık değeri -1,270, basıklık değeri ise 3,278 olarak hesaplanmıştı. Her iki ölçek için çarpıklık ve basıklık değerleri alan yazında belirtilen aralıklarda yer aldığı için veri setinin normal dağıldığı kabul edilmiş olup, bu durum parametrik testlerin uygulanabileceğini göstermektedir.

Öğretmenlerin algılanan örgütsel destek ve işe adanmışlık düzeylerinde cinsiyet, medeni durum ve branşları için "Bağımsız Örneklemler t-Testi"; eğitim durumu için ise "Tek Yönlü Varyans Analizi (ANOVA)" kullanılmıştır. Ayrıca, algılanan örgütsel destek ve işe adanmışıı arasındaki ilişkinin varlığını, yönünü ve düzeyini tespit etmek amacıyla korelasyon ve regresyon analizleri kullanılmıştır. Araştırmadaki istatistikî çözümlemeler için anlamlıık düzeyi 0,05 olarak kabul edilmiştir.

\section{3. Bulgular}

3.1. Algılanan Örgütsel Destek ve İşe Adanmışlık Düzeylerinin Demografik Değişkenler Açısından Değerlendirilmesine illişkin Bulgular

\subsection{1. $T$ Testi Bulguları}

Demografik özelliklere göre araştırmanın temel değişkenlerinin nasıl farklılaştı̆̆ını belirleyebilmek amacıyla cinsiyet, medeni durum ve alan için bağımsız örneklemler t testi yapılmış ve sonuçlar Tablo 2'de gösterilmiştir.

Tablo 2: Algılanan Örgütsel Destek ve İşe Adanmışlık Düzeylerinin Cinsiyet, Medeni Durum ve Alan Değişkenleri Açısından Değerlendirilmesi

\begin{tabular}{rccc}
\hline & $N$ & Algılanan Örgütsel Destek $(\mathrm{X} \pm \mathrm{Ss})$ & i̇şe Adanmışlık $(\mathrm{X} \pm \mathrm{Ss})$ \\
\hline $\begin{array}{r}\text { Cinsiyet } \\
\text { Kadın }\end{array}$ & 139 & $3,54 \pm 0,86$ & \\
Erkek & 213 & $3,89 \pm 0,80$ & $4,11 \pm 0,66$ \\
\hline & $\mathrm{t}=-3,841$ & $\mathrm{p}=, 000$ & $\mathrm{t}=-1,21 \pm 0,64$ \\
\hline
\end{tabular}




\begin{tabular}{|c|c|c|c|}
\hline & $\mathrm{N}$ & 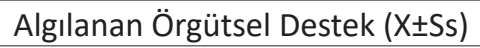 & 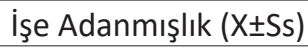 \\
\hline \multicolumn{4}{|c|}{ Medeni durum } \\
\hline Evli & 325 & $3,74 \pm 0,84$ & $4,18 \pm 0,64$ \\
\hline \multirow[t]{2}{*}{ Bekar } & 27 & $3,81 \pm 0,83$ & $4,03 \pm 0,69$ \\
\hline & & $t=-0,390 \quad p=0,697$ & $t=1,177 \quad p=0,240$ \\
\hline \multicolumn{4}{|l|}{ Alan } \\
\hline Sinif & 149 & $3,82 \pm 0,91$ & $4,38 \pm 0,52$ \\
\hline \multirow[t]{2}{*}{ Branş } & 203 & $3,70 \pm 0,79$ & $4,02 \pm 0,69$ \\
\hline & & $t=1,285 \quad p=0,200$ & $t=5,374 \quad p=0,000$ \\
\hline
\end{tabular}

Tablo 2 incelendiğinde öğretmenlerin örgütsel destek algı düzeylerinin cinsiyete göre anlamlı bir şekilde farklılaşt̆ğı görülmektedir. Ortalamalara bakıldığında erkek öğretmenlerin örgütsel destek algı düzeylerinin kadın öğretmenlerle kıyaslandığında daha yüksek olduğu görülmektedir. Katılımcıların işe adanmışlık düzeylerinde ise cinsiyet açısından istatistikî olarak anlamlı bir farklılık bulunamamıştır.

Katılımcıların algılanan örgütsel destek ve işe adanmışlık düzeylerinde medeni durum açısından istatistikî olarak anlamlı bir farklılık bulunamamıştır. Yani katılımcıların evli veya bekâr olmalarının onların algılanan örgütsel destek ile işe adanmışlık düzeylerini etkilemediği söylenebilir.

Katılımcıların algılanan örgütsel destek düzeylerinde alan değişkenine göre istatistiksel açıdan anlamlı bir farklılık bulunamamıştır. Ancak katılımcıların işe adanmışlık düzeylerinin alanlarına göre anlamlı bir şekilde farklılaştı̆ı ve ortalamalar incelendiğinde sınıf öğretmenlerinin işe adanmışlık düzeylerinin branş öğretmenlerine göre daha yüksek olduğu görülmektedir.

\subsubsection{Tek Yönlü Varyans Analizi (ANOVA) Bulguları}

Katılımcıların algılanan örgütsel destek ve işe adanmışlık düzeylerinin eğitim durumu değişkenine göre farklılıklarını belirleyebilmek amacıyla tek yönlü varyans analizi yapılmış olup sonuçlar Tablo 3'te gösterilmiştir.

Tablo 3: Algılanan Örgütsel Destek ve İşe Adanmışlık Düzeylerinin Eğitim Durumu Değişkeni Açısından Değerlendirilmesi

\begin{tabular}{lcccccccc}
\hline & \multicolumn{2}{c}{ Ön Lisans } & \multicolumn{2}{c}{ Lisans } & \multicolumn{2}{c}{ Lisansüstü } & \multicolumn{2}{c}{ ANOVA Sonuçları } \\
\cline { 2 - 9 } & $\bar{X}$ & ss. & $\bar{X}$ & ss. & $\bar{X}$ & ss. & $\mathrm{F}$ & $\mathrm{p}$ \\
\hline Algılanan Örgütsel Destek & 3,77 & 0,92 & 3,75 & 0,83 & 3,54 & 0,61 & 0,411 & 0,663 \\
İşe Adanmışlık & 4,41 & 0,45 & 4,12 & 0,68 & 4,17 & 0,48 & 4,611 & 0,011 \\
\hline
\end{tabular}

Tablo 3 incelendiğinde katılımcıların algılanan örgütsel destek düzeylerinde eğitim durumu bakımından istatistikî olarak anlamlı bir farklılık bulunmazken işe adanmışlık düzeylerinin eğitim durumlarına göre anlamlı bir şekilde farklılaştğı görülmektedir. Bu farklılığın hangi gruplardan kaynaklandığını tespit etmek amacıyla yapılan Tukey testi sonuçları, ön lisans eğitimi almış öğretmenlerin işe adanmışlık düzeylerinin lisans eğitimi almış öğretmenlere göre daha yüksek olduğunu göstermektedir.

\subsection{Algılanan Örgütsel Destek ve İşe Adanmışlık Arasındaki İlişki İle illgili Bulgular}

Algılanan örgütsel destek ve işe adanmışıı arasındaki ilişkiyi test etmek için ilk olarak korelasyon analizi yapılmış ve aralarında ilişki olduğu tespit edildikten sonra yapıların birbirlerine olan etki düzeyini belirleyebilmek amacıyla regresyon analizi yapılmıştır. Yapılan analiz sonuçları Tablo 4'te gösterilmiştir.

Tablo 4: Algılanan Örgütsel Desteğin İşe Adanmışlık Üzerindeki Etkisini Belirlemeye Yönelik Basit Regresyon Analizi

\begin{tabular}{lccccc}
\hline & \multicolumn{2}{c}{ Standardize Edilmemiş Katsayılar } & \multicolumn{2}{c}{ Standardize Edilmiş Katsayılar } & Anlamlılık Düzeyi \\
\cline { 2 - 6 } & Beta & Standart Hata & Beta & t & Sig. \\
\hline Sabit & 3,065 & 0,146 & & 20,97 &, 000 \\
Algılanan Örgütsel Destek & 0,296 & 0,038 & 0,384 & 7,78 &, 000 \\
\hline Korelasyon Katsayısı (R) & & & 0,384 & \\
Belirlilik Katsayısı (R $\left.{ }^{2}\right)$ & & 0,147 & & \\
Düzeltilmiş R & & & 0,145 & \\
Tahmini Standart Hata & & & 0,600 & \\
\hline
\end{tabular}


Tablo 4 incelendiğinde algılanan örgütsel destek ile işe adanmışlık arasında pozitif yönlü $(0,384)$ ve anlamlı $(p<0,05)$ bir ilişki olduğu görülmektedir. Bu durum, temel araştırma problemi olan ilişkinin varlı̆ııın doğrulandığını göstermektedir. Belirlilik katsayısı ( $R^{2}$, modelin açıklama gücünü göstermektedir. Dolayısıyla işe adanmışlı̆ıı \%14,7'lik kısmı algılanan örgütsel destek ile açıklanabilmektedir. Diğer bir ifadeyle tabloda yer alan veriler, çalışanların işe adanmışlıklarının $\% 14,7\left(R^{2}=0,147\right)$ oranında algılanan örgütsel destek düzeylerine bağlı olduğunu göstermektedir. Hesaplanan regresyon katsayısına göre, algılanan örgütsel destek düzeyindeki bir birimlik artış, işe adanmışlık düzeyinde 0,29 birimlik bir artışa neden olmaktadır.

\section{Tartışma, Sonuç ve Öneriler}

Öğretmenlerin örgütsel destek algıları ile kendilerini yaptıkları işe adamaları arasındaki ilişkiyi inceleyen araştırmada, örgütsel destek algı düzeylerinin cinsiyete göre anlamlı bir şekilde farklılaştı̆̆ı ve erkek öğretmenlerin örgütsel destek algılarının kadın öğretmenlere göre daha yüksek olduğu ortaya çıkmıştır. Erkek öğretmenlerin örgütsel destek algı düzeylerinin kadın öğretmenlere göre daha yüksek çıkması, okul idarecilerinin ağılıklı olarak erkek olmalarıyla ilişkilendirilebilir. Rhoades ve Eisenberger (2002), yapmış oldukları meta analizi çalışmasında bu bulguyu destekleyecek sonuçlara ulaşmışlardır. Benzer şekilde Yoon ve Lim (1999) üniversite hastanelerinde çalışanlarla yaptıkları araştırma sonucunda, erkek çalışanların kadın çalışanlara göre örgütsel desteği daha çok algıladıklarını belirtmişler ve bunun nedenini ise Kore kültüründe kadınlara kıyasla erkeklere daha çok değer verilmesi ile açıklamışlardır. Katılımcıların işe adanmışlık düzeylerinde ise cinsiyete göre istatistiksel açıdan anlamlı bir farklılık bulunamamıştır. Diğer bir ifadeyle katılımcıların kadın veya erkek olmalarının onların işe adanmışık düzeylerini etkilemediği söylenebilir. Bu sonuç, Nigah, Davis ve Hurrel (2012) tarafindan hizmet sektörü çalışanları ile gerçekleştirilen çalışmanın sonuçları ile örtüşmektedir. Zhang ve diğerleri (2014) tarafindan Avustralya'da 439 satış asistanı ile yapılan çalışmada da işe adanmışlık düzeyinin çalışanların cinsiyetine göre farklılaşmadığı sonucuna ulaşıımıştır. Benzer şekilde Turhan, Demirli ve Nazik (2012), sınıf öğretmenlerinin mesleğe adanmışık düzeylerini etkileyen faktörlere yönelik yapttkları araştırmada, öğretmenlerin mesleğe adanmışık düzeylerinin cinsiyete göre farklılaşmadığını tespit etmişlerdir. Buna karşın Banihani, Lewis ve Syed (2013), işe adanmışlığın cinsiyete göre farklılaştığı üzerine kurguladıkları ve buna dayalı bir model oluşturdukları kavramsal çalışmalarında varsayımlarını, yazınsal olarak destekleyen kuramlara dayandırarak doğrulamışlardır. Çalışanların işe adanmışlık düzeylerinin cinsiyet değişkenine yönelik araştırma sonuçlarında ortaya çıkan bu farklıığın nedeni, araştırma yöntemi ve üzerinde çalışılan örneklem gruplarının farklı olmasından kaynaklanabilir.

Katılımcıların algılanan örgütsel destek ve işe adanmışlık düzeylerinde medeni durum açısından istatistikî olarak anlamlı bir farklılık bulunamamıştı. Bu durum, katılımcıların evli veya bekâr olmalarının onların algılanan örgütsel destek ile işe adanmışlık düzeylerini önemli düzeyde etkilemediği şeklinde değerlendirilebilir. Bu sonuçla örtüşen bir şekilde, Kaur ve Aneet (2017) tarafindan bankacılar örnekleminde ve Büyükgöze (2014) tarafindan ise lise öğretmenleriyle yapılan araştırma sonuçları da çalışanların medeni durumlarının algılanan örgütsel destek düzeyinde anlamlı bir farklıık yaratmadığını göstermektedir.

Kathlımcıların algılanan örgütsel destek düzeylerinde alan değişkenine göre istatistikî olarak anlamlı bir farklılık bulunamamıştır. Bu sonuç, sınıf öğretmenleri ile branş öğretmenlerinin örgütsel destek algılarının birbirine yakın olduğu şeklinde yorumlanabilir. Ancak katılımcıların işe adanmışlık düzeylerinin alanlarına göre anlamlı bir şekilde farklılaşth̆ı ve sınıf öğretmenlerinin işe adanmışlık düzeylerinin branş öğretmenlerine göre daha yüksek olduğu tespit edilmiştir. Bu sonuç, sınıf öğretmenlerinin öğretmenlik tutumlarının matematik, yabancı dil ve meslek dersleri öğretmenlerinden anlamlı derecede pozitif olduğunu ifade eden Güner'in (2006) araştırma sonuçlarıyla benzerlik göstermektedir. Bu durum, sınıf öğretmenlerinin dört yıl ve tüm eğitim günü boyunca aynı öğrencileri okutmaları, öğrencilerin birçok durumundan kendilerinin sorumlu olduğu düşüncesi içinde olmaları ve diğer branş öğretmenlerine göre öğrencileriyle daha fazla etkileşim içerisinde olmalarından kaynaklanabilir.

Araştırmada katılımcıların algılanan örgütsel destek düzeylerinde eğitim durumuna göre istatistikî olarak anlamlı bir farklılık bulunmamıştır. Alan yazında bu sonucu destekler nitelikte araştırmalar bulunmakla birlikte (Büyükgöze, 2014; Erdem, 2014; Fuller, Hester, Barnett ve Relyea, 2006); desteklemeyen araştrmalar da mevcuttur (Rhoades ve Eisenberger, 2002; Yoon ve Thye, 2000). Araştırmada katılımcıların işe adanmışlık düzeylerinin eğitim durumlarına göre anlamlı bir şekilde farklılaştı̆ı görülmüştür. Bu farklılığın ön lisans mezunu öğretmenler ile lisans mezunu öğretmenlerin ortalama işe adanmışlıkları arasındaki farktan kaynaklandığı ve ön lisans mezunu öğretmenlerin işe adanmışlık düzeylerinin lisans mezunu öğretmenlerinkinden daha yüksek olduğu ortaya çıkmıştı. Benzer şekilde Güner (2006) tarafindan yapılan araştırmada ön lisans mezunu öğretmenlerin, örgütsel adanma, okula adanma ve öğretime adanma puanlarının lisans ve yüksek lisans mezunu olan öğretmenlere göre daha yüksek olduğu belirlenmiştir. Bu durum, uzun yıllardan bu yana 
ön lisans mezunlarının öğretmenlik mesleğine atamalarının yapılmadığı göz önüne alındığında, bu gruptaki öğretmenlerin çoğunlukla uzun süreden beri öğretmenlik mesleğinin içerisinde yer almaları nedeniyle kendilerini mesleklerine ve dolayısıyla işlerine daha yoğun adadıkları şeklinde yorumlanabilir. Yine Celep ve diğerleri (2004) de, öğretmenlerle yapmış oldukları araştırmada eğitim düzeyi ile mesleğe adanma arasında negatif anlamlı bir ilişki olduğunu tespit etmişlerdir. Eğitim düzeyi arttkça beklentilerin de artmasının doğal olduğu ifade edilen araştırmada eğitim durumu yüksek olan öğretmenlerin mesleğe adanmışlık düzeylerinin düşük olması, beklenen bir durum olarak yorumlanmıştır.

Araştırma sonucunda, algılanan örgütsel destek ile işe adanmışlık arasında pozitif yönlü bir ilişki olduğu ortaya çıkmış ve analiz sonuçları, çalışanların işe adanmışlıklarının \%14,7 oranında algılanan örgütsel destek düzeylerine bağlı olduğunu göstermiştir. Ayrıca öğretmenlerin algılanan örgütsel destek düzeyindeki bir birimlik artş̧ın, işe adanmışlık düzeyinde 0,29 birim artşa neden olduğu görülmüştür. Benzer şekilde alan yazında algılanan örgütsel destek ve işe adanmışlık arasındaki ilişkiyi doğrulayan, farklı sektörlerde yapılmış araştırmalar bulunmaktadır. Dai ve Qin (2016), Çin'de 28 farklı şehirde 350 çalışanla gerçekleştirdikleri araştırmada algılanan örgütsel desteğin işe adanmışlığı büyük ölçüde etkilediğini belirlemişlerdir. Benzer şekilde Caesens ve Stinglhamber (2014), özel sektörde yer alan iki işletmede toplam 265 çalışan ve 112 yönetici örnekleminde yaptıkları çalışmada algılanan örgütsel desteğin işe adanmışlığı pozitif yönde etkilediği sonucuna ulaşmışlardır.

Araştırmada elde edilen sonuçlar, alan yazında algılanan örgütsel desteğin, pozitif örgütsel davranış kapsamında değerlendirilen diğer kavramlarla ilişkisini irdeleyen benzer çalışmaların sonuçlarıyla da uyumludur (Akkoç, Çalışkan ve Turunç, 2012; Alparslan, Can ve Oktar, 2014; Büyükgöze, 2014; Demircan Çakar ve Yıldız, 2009; Eğriboyun, 2013; Güney, Akalın ve IIlsev, 2007; Kaplan ve Öğüt, 2012; Turunç ve Çelik, 2010a). Alparslan, Can ve Oktar'ın (2014) araştırmasında, çalışanların örgütsel destek algıları ile örgütsel özdeşleşme düzeyleri arasında pozitif yönlü ve anlamlı bir ilişki olduğu; Turunç ve Çelik'in (2010a) araştırmasında ise çalışanların örgütsel destek algılarının örgütleriyle özdeşleşme düzeylerini anlamlı şekilde arttırdığı tespit edilmiştir. Benzer şekilde Büyükgöze (2014) öğretmenlerle yaptı̆ı araştırmada, katılımcıların algılanan örgütsel destek ile genel psikolojik sermaye düzeyleri arasında orta düzeyli ve aynı yönde bir ilişki olduğunu belirlemiştir. Demircan Çakar ve Yıldız'ın (2009) araştırmalarında örgütsel destek ve iş tatmini arasında pozitif yönde bir ilişki olduğu tespit edilmiş ve örgütsel destek algısının iş tatminini etkileyen önemli faktörlerden biri olduğu ifade edilmiştir. Güney, Akalın ve İlsev (2007), araştırmalarında algılanan örgütsel desteğin duygusal örgütsel bağ|ılığı açıklama gücünün oldukça yüksek olduğunu belirtmişlerdir. Eğriboyun (2013), yapmış olduğu araştırmada hem yöneticilerin hem de öğretmenlerin örgütsel destek algılarıyla örgütsel güven, yöneticiye güven ve örgüte güven algıları arasında orta düzeyli bir ilişki olduğunu tespit etmiştir. Kaplan ve Öğüt'ün (2012) otel çalışanları üzerine yaptıkları araştırmanın sonucunda, çalışanların örgütsel destek algısı ile duygusal ve normatif bağlıık arasında pozitif yönde, devam bağlılığı arasında ise negatif yönde ve anlamlı ilişki olduğu ortaya konmuştur.

Sonuç olarak bu araştırmada öğretmenlerin algıladıkları örgütsel destek ile işe adanmışlık düzeyleri arasında pozitif bir ilişki bulunmuştur. Bu durum örgütsel destek arttkça öğretmenlerin işe adanmışlık düzeylerinin de artacağı şeklinde yorumlanabilir. Bu açıdan değerlendirildiğinde araştırmanın, Türkiye'deki eğitim kurumlarında çalışan öğretmenlerin işe adanmışlıklarını arttırmak amacıyla okul yönetiminin öğretmenlerin fikirlerini ve refahını önemsediğini gösterip, önerilerini dikkate alarak, uygun ve verimli çalışma koşulları sağlayıp onları çalışmaya teşvik ederek destekleyici bir iklim oluşturmaya önem vermesinin gerekliliğine katkı sunacağı düşünülmektedir.

Araştırma sonucuna göre okullarda kurumun yapısı incelenerek örgütsel desteği arttracak faktörlerin neler olduğunun belirlenmesi ve örgütsel destek algısının kadınlarda neden düşük çıktığının araştırılması, çalışanlarının çoğunluğu kadınlardan oluşan (MEB, 2017) eğitim kurumlarında verimin artırılması çalışmalarına katkı sağlayabilir.

\section{Kaynakça}

Akkoç, I.., Çalışkan, A. ve Turunç, Ö. (2012). Örgütlerde gelişim kültürü ve algılanan örgütsel desteğin iş tatmini ve iş performansına etkisi: Güvenin aracılık rolü. Yönetim ve Ekonomi, 19(1), 105-135.

Alparslan, A. M., Can, A. ve Oktar, Ö. F. (2014). Algılanan örgütsel desteğin yardım etme davranışına etkisinde örgütsel özdeşleşmenin aracılık rolü: Hastane çalışanları üzerine bir araştırma. İş, Güç Endüstri Ilişkileri ve Insan Kaynakları Dergisi, 16(2), 115-128.

Ardıç, K. ve Polatcı, S. (2009). Tükenmişlik sendromu ve madalyonun öbür yüzü: İşle bütünleşme. Erciyes Üniversitesi iktisadi ve idari Bilimler Fakültesi Dergisi, 32, 21-46.

Banihani, M., Lewis, P., \& Syed, J. (2013). Is work engagement gendered?. Gender in Management: An International Journal, $28(7), 400-423$.

Bostancı, H. ve Ekiyor, A. (2015). Çalışanların işe adanmasının örgüt içi girişimciliğe etkisinin incelenmesi: Sağlık sektöründe bir uygulama. Uluslararası Sağlık Yönetimi ve Stratejileri Araştırma Dergisi, 1(1), 37-51. 
Büyükgöze, H. (2014). Lise öğretmenlerinin görüşlerine göre algılanan örgütsel destek ve psikolojik sermaye ilişkisi. Yayımlanmamış yüksek lisans tezi. Hacettepe Üniversitesi Eğitim Bilimleri Enstitüsü, Ankara.

Byrne, B. M. (2010). Structural equation modeling with amos (Second Edition). Newyork: Routledge Taylor \& Francis Group.

Caesens G., \& Stinglhamber, F. (2014). The relationship between perceived organizational support and work engagement: The role of self-efficacy and its outcomes. Revue Européenne De Psychologie Appliquée, 64(5), 259-267.

Celep, C. (1998). Eğitim örgütlerinde öğretmenlerin örgütsel adanmışlığı. Eğitim ve Bilim Dergisi, 22(108), 56-62.

Celep, C., Doyuran, Ş., Sarıdede, U. ve Değirmenci, T. (2004). Eğitim örgütlerinde çok boyutlu iş etiği ve örgütsel adanmışlık. XIII. Ulusal Eğitim Bilimleri Kurultayı, 6-9 Temmuz 2004. İnönü Üniversitesi, Eğitim Fakültesi, Malatya.

Çalışkan, S. C. (2014). Pozitif örgütsel davranış değişkenleri ile yeni araştırma modelleri geliştirme arayışları: Pozitif örgütsel davranış değişkenlerinin işe adanmışlık, tükenmişlik ve sinizm üzerine etkileri ve bu etkileşimde örgütsel adalet algısının aracılık rolü üzerine bir araşttrma. Dokuz Eylül Üniversitesi Sosyal Bilimler Enstitüsü Dergisi, 16(3), 363-382.

Dai, K., \& Qin, X. (2016). Perceived organizational support and employee engagement: Based on the research of organizational Identification and organizational justice. Open Journal of Social Sciences, 4, 46-57.

Demircan Çakar, N. ve Yıldız, S. (2009). Örgütsel adaletin iş tatmini üzerindeki etkisi: "Algılanan örgütsel destek" bir ara değişken mi?. Elektronik Sosyal Bilimler Dergisi, 8(28), 68-90.

Eğriboyun, D. (2013). Ortaöğretim okullarında görev yapan yönetici ve öğretmenlerin örgütsel güven ve örgütsel destek algıları arasındaki ilişki. Kafkas Üniversitesi Sosyal Bilimler Enstitüsü Dergisi, 12, 17-43.

Eisenberger, R., Huntington, R., Hutchison, S., \& Sowa, D. (1986). Perceived organizational support. Journol of Applied Psychology, 71 (3), $500-507$.

Erdem, H. (2014). Algılanan örgütsel destek ve kontrol odağının stresle başa çıkma yöntemleri üzerine etkileri: Psikolojik sermayenin bu süreçteki rolü ve bir alan araştırması. Yayımlanmamış doktora tezi. İnönü Üniversitesi Sosyal Bilimler Enstitüsü, Malatya.

Fuller, J. B., Hester, K., Barnett, T., \& Relyea, L. F. C. (2006). Perceived organizational support and perceived external prestige: Predicting organizational attachment for university faculty, staff, and administrators. The Journal of Social Psychology, 146(3), 327-347.

Güner, H. (2006). Öğretmenlerin adanmışlık sorunu: İstanbul ili örneğinde bir çalışma. Yayımlanmamış yüksek lisans tezi. Marmara Üniversitesi Eğitim Bilimleri Enstitüsü, İstanbul.

Güney, S., Akalın, Ç. ve İlsev, A. (2007). Duygusal örgütsel bağıılık gelişiminde algılanan örgütsel destek ve örgüt temelli öz-saygı. Hacettepe Üniversitesi Iktisadi ve Idari Bilimler Fakültesi Dergisi, 25(2), 189-211.

İnce, A. R. (2016). Algılanan örgütsel desteğin işe adanmışlık üzerindeki etkisinde yönetici desteğinin aracılık rolü. Elektronik Sosyal Bilimler Dergisi, 15(57), 649-660.

Kahn, W. A. (1990). Psychological conditions of personal engagement and disengagement at work. Academy of Management Journal, $33(4), 692-724$.

Kaplan, M. ve Öğüt, A. (2012). Algılanan örgütsel destek ile örgütsel bağlılık arasındaki ilişkinin analizi: Otel işletmelerinde bir uygulama. Süleyman Demirel Üniversitesi iktisadi ve Idari Bilimler Fakültesi Dergisi,17(1), 387-401.

Karasar, N. (2014). Bilimsel araştırma yöntemi (27. Baskı). Ankara: Nobel Yayınları.

Kasalak, G. ve Bilgin Aksu, M. (2014). Araştırma görevlilerinin algıladıkları örgütsel desteğin örgütsel sinizm ile ilişkisi. Kuram ve Uygulamada Eğitim Bilimleri, 14(1), 115-133.

Kaur, S., \& Aneet (2017). Perceived organizational support and affective commitment: A demographic analysis. IOSR Journal of Business and Management, 19(1), 54-59.

Keleş, S. (2014). Aile şirketlerinde Y jenerasyonunun öz yeterlilik algısı ve işe adanmışlık ilişkisi. Süleyman Demirel Üniversitesi Vizyoner Dergisi, 5(11), 95-109.

Kline, R. B. (2016). Principles and practice of structural equation modeling (Fourth Edition). NewYork: Guilford publications.

Maden Eyiusta, C. (2015). İşgörenlerin güçlendirme algılarının sorumluluk üstlenme davranışları üzerindeki etkisi: İşe adanmışık ve iş tatmini değişkenlerinin aracılık rolü. Dumlupınar Üniversitesi Sosyal Bilimler Dergisi, 43, 68-78.

MEB. (2017). Milli Eğitim İstatistikleri Örgün Eğitim 2016'17. http://sgb.meb.gov.tr/meb_iys_dosyalar/2017_09/08151328_meb_istatistikleri_orgun_egitim_2016_2017.pdf (Erişim Tarihi: 07.11.2017).

Nigah, N., Davis, A. J., \& Hurrel, S. A. (2012). The impact of buddying on psychological capital and work engagement: An empirical study of socialization in the professional services sector. Thunderbird International Business Review, 54(6), 891-905.

Ötken, A. B. (2015). Algılanan örgütsel destek ve psikolojik sahiplenme arasındaki ilişki ve bu ilişkide örgütsel adaletin rolü. Hacettepe Üniversitesi Iiktisadi ve Idari Bilimler Fakültesi Dergisi, 33(2), 113-140.

Özbek, M. F. ve Kosa, G. (2009). Duygusal bağlılık, örgütsel destek, üst yönetim desteği ve personel güçlendirmenin hizmet kalitesi üzerindeki etkisi: Kırgızistan'da banka işgörenleri üzerinde bir uygulama. Erciyes Üniversitesi iktisadi ve Idari Bilimler Fakültesi Dergisi, 34, $189-212$.

Özdevecioğlu, M. (2003). Algılanan örgütsel destek ile örgütsel bağlılık arasındaki ilişkilerin belirlenmesine yönelik bir araştırma. Dokuz Eylül Üniversitesi i.i.B.F.Dergisi, 18(2), 113 -130.

Özkalp, E. ve Meydan, B. (2015). Schaufeli ve Bakker tarafindan geliştirilmiş olan işe angaje olma ölçeğinin Türkçe'de güvenilirlik ve geçerliliğinin analizi. İş, Güç, Endüstri iliş̧kileri ve Insan Kaynakları Dergisi, 17(3), 4-19. 
Özyılmaz, A. ve Süner, Z. (2015). İşe adanmışlığın işyeri tutumlarına etkisi: Hatay’daki 9 işletmede yapılan ampirik araştırmanın sonuçları. Eskişehir Osmangazi Üniversitesi iiBF Dergisi, 10(3), 143-164.

Rhoades, L., \& Eisenberger, R. (2002). Perceived organizational support: A review of the literatüre. Journal of Applied Psychology, 87(4), 698-714.

Schaufeli, W. B., Salanova, M., González-romá, V., \& Bakker, A. B. (2001). The measurement of engagement and burnout: A two sample confirmatory factor analytic approach. Journal of Happiness Studies, 3(1), 71-92.

Sökmen, A., Ekmekçioğlu, E. B. ve Çelik, K. (2015). Algılanan örgütsel destek, örgütsel özdeşleşme ve yönetici etik davranışı ilişkisi: Araştırma görevlilerine yönelik araştırma. Işsletme Araştırmaları Dergisi, 7(1), 125-144.

Tokgöz, N. (2011). Örgütsel sinisizm, örgütsel destek ve örgütsel adalet ilişkisi: Elektrik dağıtım işletmesi çalışanları örneği. Eskişehir Osmangazi Üniversitesi IiBF Dergisi, 6(2), 365-389.

Turhan, M., Demirli, C. ve Nazik, G. (2012). Sınıf öğretmenlerinin mesleğe adanmışlık düzeyine etki eden faktörler: Elazığ örneği. istanbul Ticaret Üniversitesi Sosyal Bilimler Dergisi, (21), 179-192.

Turunç, Ö. ve Çelik, M. (2010a). Çalışanların algıladıkları örgütsel destek ve iş stresinin örgütsel özdeşleşme ve iş performansına etkisi. Yönetim ve Ekonomi Dergisi, 17(2), 183-206.

Turunç, Ö. ve Çelik, M. (2010b). Algılanan örgütsel desteğin çalışanların iş-aile, aile-iş çatışması, örgütsel özdeşleşme ve işten ayrılma niyetine etkisi: Savunma sektöründe bir araşttrma. Atatürk Üniversitesi Sosyal Bilimler Enstitüsü Dergisi, 14(1), $209-232$.

Uçar, D. ve Ötken, A. B. (2010). Perceived organizational support and organizational commitment: The mediating role of organization based self-esteem. Dokuz Eylül Üniversitesi Iktisadi ve Idari Bilimler Fakültesi Dergisi, 25(2), 85-105.

Yılmaz, D. (2014). Dağıtılmış liderliğin örgütsel güven ile algılanan örgütsel destek ve okul başarısıyla ilişkisi. Yayımlanmamış doktora tezi. Eskişehir Osmangazi Üniversitesi Eğitim Bilimleri Enstitüsü, Eskişehir.

Yılmaz, H. ve Görmüş, A. Ş. (2012). Stratejik girişimciliğin, algılanan örgütsel destek ve örgütsel öğrenme üzerine etkilerinin araştırılması: Tekstil sektöründe ampirik bir çalışma. Journal of Yasar University, 26(7), 4483-4054.

Yoon, J., \& Lim, J. C. (1999). Organizational support in the workplace: The case of Korean hospital employees. Human Relations, 52(7), $923-945$.

Yoon, J., \& Thye, S. (2000). Supervisor support in work place: Legitimacy and positive affectivity. The Journal of Social Psychology, 140 (3), 295-316.

Zhang, T., Avery, G. C., Bergsteiner, H., \& More, E. (2014). The relationship between leadership paradigms and employee engagement. Journal of Global Responsibility, 5(1), 4-21. 